\title{
Population dynamics of Cytophaga-Flavobacteria during marine phytoplankton blooms analyzed by real-time quantitative PCR
}

\author{
Laura B. Fandino ${ }^{1,2}$, Lasse Riemann ${ }^{1,3}$, Grieg F. Steward ${ }^{1,4}$, Farooq Azam ${ }^{1, *}$ \\ ${ }^{1}$ Marine Biology Research Division, Scripps Institution of Oceanography, University of California, San Diego, \\ California 92093-0202, USA \\ ${ }^{2}$ Present address: University of Washington, William H. Gates Hall, Seattle, Washington 98195-3020, USA \\ ${ }^{3}$ Present address: Marine Microbiology, BoM, Kalmar University, 39182 Kalmar, Sweden \\ ${ }^{4}$ Present address: Department of Oceanography, School of Ocean and Earth Science and Technology, University of Hawaii, \\ Honolulu, Hawaii 96822, USA
}

\begin{abstract}
We analyzed the dynamics of the Cytophaga-Flavobacterium (CF) cluster during a Thalassiosira sp.-dominated diatom bloom in a mesocosm and a coastal bloom of the dinoflagellate Lingulodinium polyedrum using quantitative (Taq Man) PCR. Particle colonization was tracked by quantifying CF small subunit (SSU) rDNA copies as a percentage of total bacterial SSU rDNA copies in operationally defined free-living $(<\mathrm{ca} .1 .0 \mu \mathrm{m})$ and particle-attached $(>\mathrm{ca} .1 .0 \mu \mathrm{m})$ size fractions. During both blooms, the percentage of CF rDNA in the free-living fraction was greater than in the particle-associated fraction, yet ranged widely from almost undetectable to $10-40 \%$ of total SSU rDNA. The percentage of CF rDNA copies in the attached fraction was low overall $(\leq 3.2 \%$ of total), except at the chl a peak of the dinoflagellate bloom when CF rDNA copies comprised $>50 \%$ of the total bacterial SSU rDNAs in that fraction. In addition, the timing of peaks in attached CF differed between blooms, occurring at the peak in chlorophyll a for the dinoflagellate bloom, but during the detrital phase of the diatom bloom. Our data suggests that different bloom types may encourage different attachment responses by $\mathrm{CF}$ and indicate that high abundance of $\mathrm{CF}$ during a phytoplankton bloom is transient in nature, with shifts in abundance and group composition occurring on the order of $1 \mathrm{~d}$ to a few days.
\end{abstract}

KEY WORDS: TaqMan - Cytophaga-Flavobacterium - Population dynamics · Bloom · Marine bacteria

\section{INTRODUCTION}

Members of the Cytophaga-Flavobacterium (CF) complex of the Bacteroidetes phylum are among the most abundant aquatic heterotrophic bacteria (Glöckner et al. 1999, Kirchman 2002), and studies based on clone libraries and fluorescent in situ hybridization (FISH) have indicated that CF fills a particle-specialist niche in the pelagic ocean (DeLong et al. 1993, Ploug et al. 1999) with important implications for particle degradation and carbon flux. While evidence of a particle-specialist role for CF is limited, a few trends in the distribution of this group have been reported. $\mathrm{CF}$ are commonly enriched in sea ice communities (Brinkmeyer et al. 2003), marine snow (DeLong et al. 1993, Rath et al. 1998), coastal waters (Pinhassi et al. 1999, Kirchman et al. 2003) and during phytoplankton blooms (Riemann et al. 2000, Fandino et al. 2001, Pinhassi et al. 2004). The ecological importance of this group, however, is due not only to their wide distribution and frequently high local concentrations, but also to their ability to degrade complex biomacromolecules 
(Shewan \& McMeekin 1983, Cottrell \& Kirchman 2000). The functional roles of CF are, thus, likely to be important to our understanding of marine biogeochemical processes in coastal and/or enriched (micro) environments and of mechanisms involved in the dissolution of phytodetritus and other particulate organic matter (POM) to the dissolved organic matter (DOM) phase.

While several studies have used indirect methods to infer patterns in the distribution of CF, only a few have quantitatively linked these organisms to environmental factors and conditions consistent with their presumptive role as 'particle specialists'. Direct microscopy using FISH on marine snow in the Southern Californian Bight (Ploug et al. 1999) and on aged macroaggregates from the Southern Ocean (Simon et al. 2002) showed that CF comprised 20 to $40 \%$ of the DAPI count. FISH on bulk seawater samples from the Antarctic Ocean showed that CF were numerically dominant during a Phaeocystis sp. bloom (Glöckner et al. 1999, Simon et al. 1999). These authors found that CF comprised $72 \%$ of the total DAPI count at the southern edge of a Phaeocystis bloom and 20 to $40 \%$ of the total community in samples collected outside the bloom. Further, Suzuki et al. (2001) found a negative correlation between $\mathrm{CF}$ and salinity off the California coast using the 5'-nuclease assay (TaqMan). Since salinity is a proxy for recent upwelling, the relative number of CF might be expected to increase following upwelling, after phytoplankton blooms form and then decay (Suzuki et al. 2001).

In this study we used the PCR-based TaqMan assay to estimate the relative abundance of $\mathrm{CF}$ in the freeliving and particle-associated fractions during a diatom bloom in a mesocosm (Riemann et al. 2000) and during a red-tide dinoflagellate bloom off the California coast (Fandino et al. 2001). In previous reports on these blooms, changes in the composition of free-living and particle-associated bacterial communities were investigated using the non-quantitative method of denaturing gradient gel electrophoresis (DGGE) coupled with cloning and sequencing. The results showed qualitatively that community composition changed dramatically during the blooms and that diverse CF were apparently present both as free-living cells and in association with particles, contrary to the general perception of $\mathrm{CF}$ as particle-specialists. Our specific goal in this study was to reanalyze samples from these blooms using a quantitative method in order to better assess the relative contribution of CF to free-living and attached bacterial communities and correlate these contributions with changes in bacterial metabolism and/or proxies of primary production and bloom decay (i.e. chlorophyll $a[\mathrm{chl} a]$ and particulate organic carbon [POC]).

\section{MATERIALS AND METHODS}

Mesocosm bloom. The experimental design for the mesocosm bloom is detailed in Riemann et al. (2000). In brief, surface seawater (0.5 m depth) was collected off the pier at Scripps Institution of Oceanography (California) in December 1997. The seawater was prefiltered (33 $\mu \mathrm{m}$ Nitex) to remove macrozooplankton and added to 2001 polyethylene tanks. Diatom blooms, dominated by Thalassiosira sp., were stimulated in the mesocosms via the addition of nutrients $\left(\mathrm{NaH}_{2} \mathrm{PO}_{4}\right.$ [1.0 $\mu \mathrm{M}], \mathrm{Na}_{2} \mathrm{SiO}_{3}[10.8 \mu \mathrm{M}]$, and $\left.\mathrm{NaNO}_{3}[6.9 \mu \mathrm{M}]\right)$. Duplicate tanks were maintained at $18^{\circ} \mathrm{C}$ and were exposed to a 12:12 h light:dark cycle.

Sample collection. Samples were collected during the dinoflagellate Lingulodinium polyedrum bloom as described in Fandino et al. (2001) and during the diatom bloom as described in Riemann et al. (2000). The contribution of particle-associated bacteria to carbon flux was estimated as the difference between measurements on unfiltered and filtered seawater, where filtration was through glass-fiber filters with a nominal pore size of $1.2 \mu \mathrm{m}$ (Whatman, GF/C) for the dinoflagellate bloom and through $1.0 \mu \mathrm{m}$ pore-size polycarbonate membranes (Poretics) for the diatom bloom. During the dinoflagellate bloom, samples were collected every 1 to $3 \mathrm{~d}$ during the period 30 April to 30 May and then weekly until the end of June 1997 for analyses of carbon dynamics. Seawater samples for DNA extraction were collected on 5, 7, 9, 13 and 30 May and 9 and 25 June 1997. During the diatom bloom, samples were collected daily for analyses of carbon dynamics and every second day for bacterial community DNA throughout the $16 \mathrm{~d}$ experiment.

Chl $a$, POC and bacterial abundance. The data have been adapted from Fandino et al. (2001) and Riemann et al. (2000). Briefly, chl a was measured by ethanol extraction and spectrophotometry by the method of Jespersen \& Christoffersen (1987). POC was filtered onto precombusted Whatman GF/F filters and analyzed using a Perkin Elmer Model 2400 CHN analyzer. POC:phytoplankton carbon (phytoC) ratios were calculated by applying a carbon:chl a ratio of 50 (Redalje 1983). Bacteria were enumerated in unfiltered and $<1.0 \mu \mathrm{m}$ filtered samples by DAPI $\left(4^{\prime}, 6\right.$-diamidino-2phenylindole) epifluorescence direct counts (Porter \& Feig 1980).

DNA preparation. Free-living and particle-associated community DNA was obtained during the dinoflagellate bloom as described in Fandino et al. (2001). During the mesocosm experiment, seawater samples for bacterial DNA isolation (2 to 3 l) were filtered sequentially through $1.0 \mu \mathrm{m}$ pore size polycarbonate filters (Nuclepore, $142 \mathrm{~mm}$ diameter) and $0.22 \mu \mathrm{m}$ pore size Sterivex capsule filters (Millipore). 
Bacteria collected on the polycarbonate filters were operationally defined as particle-associated while those passing through the polycarbonate filters, but retained by the capsule filter, were defined as freeliving. The $>1.0 \mu \mathrm{m}$ bacterial size fraction was isolated from the Nuclepore filters as described in Fandino et al. (2001), while the $<1.0 \mu \mathrm{m}$ bacterial size fraction was extracted from the Sterivex capsule filters as described in Riemann et al. (2000). During the mesocosm bloom, additional samples were filtered directly onto the sterivex capsule filters to obtain unfiltered bacterial community DNA, as reported in Riemann et al. (2000). All extracted DNA was further purified using the DNeasy ${ }^{\mathrm{TM}}$ tissue kit (Qiagen) prior to the TaqMan assay.

The 5'-nuclease (TaqMan) assay. The quantitative TaqMan assay is based on measurements of fluorescence by reporter molecules released during PCR (Livak et al. 1995) and on the number of cycles required to achieve a threshold value. This value can then be related to amplicon quantity using a standard curve. The primers and probes (Table 1) used target 'universal' bacterial or CF-specific sequences within the 16S rRNA gene. The forward primer (191F, Suzuki et al. 2001) was modified for use in this study to avoid mismatch with a Cellulophaga spp. group commonly found in marine waters, although both primers were found to amplify with similar efficiency in later preliminary tests. The probes were synthesized with a reporter dye on the 5' end (FAM-6-carboxyfluorescein) and a quencher molecule (TAMRA-6-carboxytetramethylrhodamine) on the 3 ' end (PE Applied Biosystems). The CF-specific probe was based on that of Manz et al. (1996) as modified by Suzuki et al. (2001). It should be noted that originally this probe targeted only $\sim 90 \%$ of the available database CF sequences (Manz et al. 1996).
The optimized reaction components for the TaqMan assay included the following: 1 to $5 \mathrm{ng}$ DNA template; $3 \mathrm{mM} \mathrm{MgCl}_{2} ; 0.25 \mathrm{U}$ AmpErase uracil $\mathrm{N}$-glycosylase (Applied Biosystems); $0.2 \mathrm{mM}$ each dATP, dGTP, dCTP and $0.4 \mathrm{mM}$ dUTP; $0.7 \mathrm{U}$ platinum Taq DNA polymerase (Invitrogen) and $1 \times$ of the corresponding amplification buffer (Invitrogen). The concentrations of the primers and probes are given in Table 1. Samples were prepared by adding all reaction components into LightCycler capillaries (Roche Diagnostics) maintained at $4^{\circ} \mathrm{C}$ in a chilled block. Samples were then centrifuged briefly at $1000 \times g$ in the pre-chilled centrifuge adapters. The LightCycler amplification conditions included an initial 2 min incubation at $50^{\circ} \mathrm{C}$ and a single $94^{\circ} \mathrm{C}$ denaturation step, followed by 40 cycles of denaturation $\left(94^{\circ} \mathrm{C}, 15 \mathrm{~s}\right)$ and combined extension/annealing $\left(56\right.$ or $58^{\circ} \mathrm{C} ; 1 \mathrm{~min}$ 20 s); 2 reactions were run per sample and the data were plotted as the average of replicate samples.

Preparation of standard for 5'-nuclease (TaqMan) assay. A marine CF isolate (GenBank Accession No. AY030100) isolated from the dinoflagellate bloom was used to prepare an rDNA standard for the assay. A plasmid containing the SSU-internal transcribed spacer-LSU rDNA of this isolate (PCR primers 27F [5'-AGAGTTTGATCMTGGCTCAG-3'] and 1933eR [5'-ACCCGACAAGGAATTTCG C-3']) was prepared as described previously (Suzuki et al. 2000). Plasmids were purified using the Qiagen ${ }^{\circledR}$ plasmid maxi kit (Qiagen), and further purified using $\mathrm{CsCl}$ gradient centrifugation and standard methods (Sambrook et al. 1989). Subsamples of the purified plasmid preparations were linearized by Not 1 restriction digestion as recommended for the TaqMan assay (Roche LightCycler user manual). PicoGreen quantification was performed using the 96-well format in accordance with the manufacturer's instructions (Molecular Probes) using a Perkin Elmer HTS 7000 Bio Assay Reader.

Table 1. Oligonucleotide sequences and reaction conditions for TaqMan assay

\begin{tabular}{|c|c|c|c|c|}
\hline $\begin{array}{l}\text { Set name } \\
\text { (Target group) }\end{array}$ & Type & $\begin{array}{c}5 \text { ' to } 3 \text { ' sequence } \\
\text { (optimal concentration) }\end{array}$ & Temp./MgCl${ }_{2}$ & Source \\
\hline \multirow[t]{3}{*}{$\begin{array}{l}\text { BACT2 } \\
\text { (Bacteria) }\end{array}$} & Forward primer & $\begin{array}{l}\text { BACT1369F (1500 nM) } \\
\text { CGGTGAATACGTTCYCGG }\end{array}$ & \multirow[t]{3}{*}{$58^{\circ} \mathrm{C} / 3 \mathrm{mM}$} & \multirow[t]{3}{*}{$\begin{array}{l}\text { Suzuki et al. (2000) and } \\
\text { Present study }\end{array}$} \\
\hline & Reverse primer & $\begin{array}{l}\text { PROK1492R (1000 nM) } \\
\text { GGWTACCTTGTTACGACTT }\end{array}$ & & \\
\hline & Probe & $\begin{array}{l}\text { TM1389F }(500 \mathrm{nM}) \\
\text { CTTGTACACACCGCCCGTC }\end{array}$ & & \\
\hline \multirow[t]{3}{*}{$\begin{array}{l}\text { CYTOP } \\
\text { (Cytophagales) }\end{array}$} & Forward primer & $\begin{array}{l}\text { CYT191F (500 nM) } \\
\text { GGGYCCTGAGAGGGRGAT }\end{array}$ & \multirow[t]{3}{*}{$56^{\circ} \mathrm{C} / 3 \mathrm{mM}$} & \multirow[t]{3}{*}{$\begin{array}{l}\text { Suzuki et al. (2001) and } \\
\text { Present study }\end{array}$} \\
\hline & Reverse primer & $\begin{array}{l}\text { CYT536R }(1000 \mathrm{nM}) \\
\text { GTATTACCGCGGCTGC }\end{array}$ & & \\
\hline & Probe & $\begin{array}{l}\text { TM311F }(400 \mathrm{nM}) \\
\text { CCACACTGGTACTGAGACACGGAC }\end{array}$ & & \\
\hline
\end{tabular}



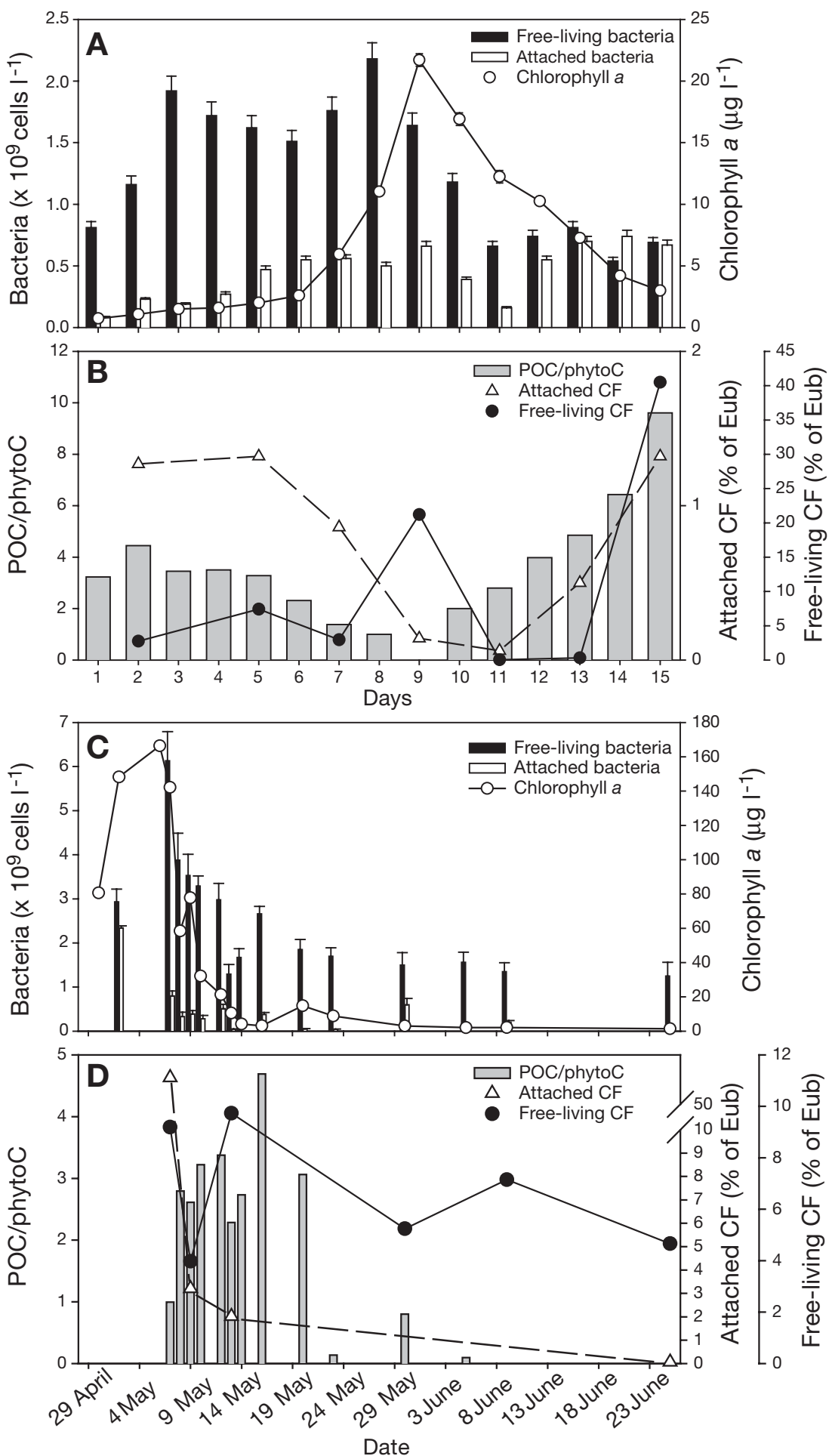

Fig. 1. Blooms of $(A, B)$ diatoms (mesocosm experiment) and $(\mathrm{C}, \mathrm{D})$ dinoflagellates in April to June 1997, showing (B,D) Cytophaga-Flavobacterium (CF) SSU rDNAs as a percentage of total bacterial SSU rDNA (Eub) in free-living and particle-associated size-fractions during (B) diatom bloom and (D) dinoflagellate bloom in relation to changes in the ratio of total particulate organic carbon (POC) to phytoplankton carbon (phytoC). $(\mathrm{A}, \mathrm{C})$ Changes in $\mathrm{chl} a$ and total bacterial abundance in free-living and particle-associated size-fractions (for reference); bacterial abundance, chl $a$ and POC values from Riemann et al. (2000) and Fandino et al. (2001)

\section{RESULTS AND DISCUSSION}

As previously reported (Riemann et al. 2000, Fandino et al. 2001), and reproduced herein for context, the diatom and dinoflagellate blooms were intense, with chl a concentrations reaching 20 and $170 \mu \mathrm{g} \mathrm{l}^{-1}$, respectively (Fig. 1A,C). Bacterial abundance peaked at ca. 3 and $6 \times$ $10^{9} \mathrm{l}^{-1}$, respectively, and in both studies bacteria were predominantly in the freeliving size fraction, except during the detrital phase of the diatom bloom when the numbers of bacteria in the free-living and attached fractions were comparable (Fig. 1A,C).

\section{Dynamics of free-living and particle-associated $\mathrm{CF}$}

The percent contribution of CF SSU rDNA to total bacterial SSU rDNA was highly variable in both the particle-associated and free-living size fractions (Fig. 1B,D). In all but one instance, CF comprised $\leq 3.2 \%$ of the attached bacterial SSU rDNA copies. The one exception was the strong peak $(52.7 \%$ of total bacterial SSU rDNAs) in the particleassociated fraction at the chl a peak of the dinoflagellate bloom (Fig. 1D). The contribution of $\mathrm{CF}$ to the free-living bacterial SSU rDNA, in contrast, was 4.0 to $9.7 \%$ during the dinoflagellate bloom and 0.1 to $40.5 \%$ during the diatom bloom. In the latter case, 2 major peaks occurred on Day $9(21.2 \%)$ and Day 15 (40.5\%) of the experiment.

While early results suggested that CF would primarily be found on particles (DeLong et al. 1993, Rath et al. 1998), more recent data obtained by qualitative analyses (DGGE, sequencing) suggest that this is not always the case (Fandino et al. 2001). The present TaqMan PCR analyses further support the suggestion that CF can be important components of the free-living communities under nutrient-rich conditions.

Somewhat surprising was the generally low contribution of $\mathrm{CF}$ to the particleassociated communities. Since the primer-probe set used does not recognize all members of the CF cluster (Weller 
et al. 2000) the contribution of particle-associated CF could be underestimated. Further, the eubacterial primer and probe set does not discriminate between bacterial and plastid rDNA. Since diatoms and dinoflagellates would be collected on the $1.0 \mu \mathrm{m}$ filters, plastid DNA is likely to contribute to the total rDNA copy number in the particle fraction, lowering the apparent contribution of CF to the attached bacterial community. Despite this potential source of error, CF contributed the majority of rDNA copies in the particulate fraction at the peak of the dinoflagellate bloom when one would expect this bias to be worst.

Our results are reported, as in other studies (Suzuki et al. 2000, 2001), as relative percentages of rDNA copy numbers rather than absolute or relative cell counts. Absolute quantification of cell numbers would require knowledge of SSU rDNA copy number per genome and genome copies per cell (which is a function of growth rate) for all members of the community. To obtain rough estimates of the absolute cell numbers of $\mathrm{CF}$, however, we can make the simplifying assumption that rDNA copy number and genomes per cell are the same for all populations in the community. Estimates of the absolute abundance of CF are then obtained by multiplying total cell counts by the percentage of CF relative to total SSU rDNAs as measured by TaqMan.

Abundances calculated using this conversion suggest that particle-associated CF numbers were generally low and ranged from 0.1 to $9 \times 10^{6} \mathrm{l}^{-1}$ and from almost undetectable to $4 \times 10^{8} \mathrm{l}^{-1}$ during the diatom and dinoflagellate blooms, respectively. Free-living CF were typically more abundant, reaching abundances of $4 \times 10^{8} \mathrm{l}^{-1}$ (diatom bloom) and $6 \times 10^{8} \mathrm{l}^{-1}$ (dinoflagellate bloom). The exception was at the dinoflagellate chl a peak ( 7 May) when the numbers of attached CF roughly equaled free-living CF (4 and $6 \times 10^{8} \mathrm{l}^{-1}$, respectively). These estimates further illustrate that $\mathrm{CF}$ can be quantitatively important members of both freeliving and attached bacterial communities during phytoplankton blooms.

\section{Percentage CF relative to POM dynamics}

The dynamics of CF SSU rDNA in the attached and free-living fractions in the 2 blooms were compared to changes in the ratio of total POC to phytoplankton $\mathrm{C}$ (Fig. 1B,D) to determine how attachment relates to POC quality. The frequency of sample collection during the diatom bloom allowed us to monitor changes in percent CF rDNA both during the bloom (decline in POC/phytoC up to Day 9) and during the subsequent detrital phase (increase in POC/phytoC after Day 9; Fig. 1A,B). During the bloom, the dynamics of particle- associated $\mathrm{CF}$ roughly tracked the $\mathrm{POC} /$ phytoC ratio while a peak in free-living $\mathrm{CF}$ coincided with the peak in chl a. The decline in CF contribution to the freeliving community from Days 9 to 13 occurred as CF representation in the attached community was increasing, suggesting enhanced colonization of diatom detritus by $\mathrm{CF}$ as the bloom declined. During the final stage of the experiment, ectoenzyme activities were high and POC was declining (Riemann et al. 2000), indicating solubilization of detrital particles. The proportion of free-living $\mathrm{CF}$ increases again in this final stage (Day 15).

During the dinoflagellate bloom, sample collection encompassed the peak in chl $a$ and the demise of the bloom, with 2 additional samples analyzed 2 to $3 \mathrm{wk}$ into the post-bloom phase (Fig. 1C,D). In contrast to the mesocosm diatom bloom, the percentages CF in both size fractions were high around the peak in chl $a$, and attached $\mathrm{CF}$ accounted for almost half the total CF community. The large fraction of attached CF at the chl a peak (as opposed to during the detrital phase) and the concomitant peak in per cell aminopeptidase activity (>6500 amol cell $\mathrm{h}^{-1}$; Fandino et al. 2001) is intriguing, since living phytoplankton comprised a large part of the total POC at this time (POC/ phytoC $\approx 1$, Fig. 1D). The prevalence of attached CF at this time may be due to the quality and concentration of the organic material produced at the peak of the bloom, or possibly due to a direct association with the dinoflagellates. It is notable that the maxima of attached bacterial carbon production and ectoenzyme activities occurred at different stages of the 2 blooms (Riemann et al. 2000, Fandino et al. 2001), but in each case were coincident with the maximum abundance of attached CF. The apparent differences in the timing of bacterial responses to the 2 blooms may have been caused by sampling a closed versus open system, but inherent differences in the bloom-forming species is also likely to have been an important contributing factor. Variations in DOM leakage from different phytoplankton species or the excretion of antibacterial substances, for example, could have influenced the colonization of algal cells (see Cole 1982). Our findings are in accordance with a recent study by Pinhassi et al. (2004), who found that a phytoflagellate-dominated and a diatom-dominated phytoplankton bloom had significantly different effects on bacterial community composition in mesocosms. Also relevant to our study, was the observation that members of the Flavobacteriaceae family, in particular, were remarkably responsive to phytoplankton blooms (Pinhassi et al. 2004).

Rapid increases in the percentage of CF SSU rDNA during both blooms could have been due to rapid growth of CF phylotypes and/or limited grazing pressure on these organisms. For example, Pinhassi et al. 
(1999) found that a CF type achieved a net growth rate approximately 5 times faster than community turnover times in a protein enriched mesocosm study. During the late stages of the diatom bloom, the increased percentage of $\mathrm{CF}$ in both the free and attached fractions correlated with a $>4$-fold $\left(1.2 \times 10^{6}\right.$ to $\left.5.3 \times 10^{6} \mathrm{l}^{-1}\right)$ increase in flagellate numbers (Riemann et al. 2000), suggesting that grazing-resistant CF types may have developed following the crash in total bacterial abundance and in percentage CF rDNA on Days 9 to 11 (Fig. 1A,B). Formation of filamentous CF morphotypes has previously been observed as a response to pronounced grazing pressure (Jürgens et al. 1999) and, indeed, a dominance of filamentous bacteria was observed towards the end of the mesocosm experiment (Riemann et al. 2000).

During both blooms, the changes in the percentage of CF SSU rDNAs measured by the TaqMan assay agreed with the appearance and disappearance of CF-related phylotypes using DGGE and 16S rDNA sequencing (Riemann et al. 2000, Fandino et al. 2001). For example, Riemann et al. (2000) found the relative dominance of a single phylotype related to $\mathrm{CF}$ at the peak of the diatom bloom (Fig. 4 in Riemann et al. 2000, Band 7). This phylotype disappeared on Day 11 of their experiment (the POC peak) alongside a pronounced shift in bacterial community structure. Likewise, we found in the present study that the free-living CF population declined by approximately 3 orders of magnitude between Days 9 and 11 (Fig. 1B). DGGE analyses also showed the appearance and relative dominance of 2 new CF-related phylotypes at the end of the post-bloom phase (Fig. 4 in Riemann et al. 2000, Bands 3 and 4), which agrees with the rapid growth rates of both free- $\left(2.6 \mathrm{~d}^{-1}\right)$ and attached CF $\left(1.6 \mathrm{~d}^{-1}\right)$ during this period (estimated from cell counts and the percentages of CF SSU rDNAs). The compatibility of the DGGE and TaqMan results indicates that DGGE may offer semi-quantitative information on population variations, as suggested previously (Riemann et al. 1999, Casamayor et al. 2000, Castle \& Kirchman 2004), although the actual abundance of the phylotypes within the CF community is unknown.

\section{CONCLUSIONS}

While this study confirms the overall importance of $\mathrm{CF}$ during the course of marine phytoplankton blooms, it also emphasizes the role of CF not only in particle colonization and degradation but, more surprisingly, as a substantial fraction of the free-living community, perhaps playing important roles in the degradation of high molecular weight DOM. Our results suggest that different bloom types may encourage different $\mathrm{CF}$ attach- ment behaviors. High percentages of free-living $\mathrm{CF}$ at high chl a levels during both blooms may have been caused by high phytoplankton exudation rates related to nutrient depletion (Larsson \& Hagström 1982, Lancelot 1983). Our data strongly suggest that high abundance of CF (and possibly other bacterial groups) during phytoplankton blooms is transient in nature with rapid shifts in abundance and group composition on the order of $1 \mathrm{~d}$ to a few days. These results stress the need for fine-resolution temporal analyses of taxon-specific bacterial abundance and activities for the accurate assessment of potential biogeochemical roles.

Acknowledgements. We thank E. F. DeLong for technical advice on the TaqMan assay and S. Tsai for technical assistance. This work was supported by NSF grants (OCE 9819603, OPP95-30851, and OPP96-17045) to F.A. and NSF grant OCE00-75927.

\section{LITERATURE CITED}

Brinkmeyer R, Knittel K, Jürgens J, Weyland H, Amann R, Helmke E (2003) Diversity and structure of bacterial communities in Arctic versus Antarctic pack ice. Appl Environ Microbiol 69:6610-6619

Casamayor EO, Schäfer H, Baneras L, Pedrós-Alió C, Muyzer G (2000) Identification of and spatio-temporal differences between microbial assemblages from two neighboring sulfurous lakes: comparison by microscopy and denaturing gradient gel electrophoresis. Appl Environ Microbiol 66:499-508

Castle D, Kirchman DL (2004) Composition of estuarine bacterial communities assessed by denaturing gradient gel electrophoresis and fluorescence in situ hybridization. Limnol Oceanogr Methods 2:303-314

Cole JJ (1982) Interactions between bacteria and algae in aquatic ecosystems. Annu Rev Ecol Syst 13:291-314

Cottrell MT, Kirchman DL (2000) Natural assemblages of marine Proteobacteria and members of the CytophagaFlavobacter cluster consuming low- and high-molecularweight dissolved organic matter. Appl Environ Microbiol 66:1692-1697

DeLong EF, Franks DG, Alldredge AL (1993) Phylogenetic analysis of aggregate-attached versus free-living marine bacterial assemblages. Limnol Oceanogr 38:924-934

Fandino LB, Riemann L, Steward GF, Long RA, Azam F (2001) Variations in bacterial community structure during a dinoflagellate bloom analyzed by DGGE and 16S rDNA sequencing. Aquat Microb Ecol 23:119-130

Glöckner FO, Fuchs BM, Amann R (1999) Bacterioplankton compositions of lakes and oceans: a first comparison based on fluorescence in situ hybridization. Appl Environ Microbiol 65:3721-3726

Jespersen AM, Christoffersen K (1987) Measurements of chlorophyll-a from phytoplankton using ethanol as extraction solvent. Arch Hydrobiol 109:445-454

Jürgens K, Pernthaler J, Schalla S, Amann R (1999) Morphological and compositional changes in a planktonic bacterial community in response to enhanced protozoan grazing. Appl Environ Microbiol 65:1241-1250

Kirchman DL (2002) The ecology of Cytophaga-Flavobacteria in aquatic environments. FEMS Microbiol Ecol 39:91-100 
Kirchman DL, Yu L, Cottrell MT (2003) Diversity and abundance of uncultured Cytophaga-like bacteria in the Delaware Estuary. Appl Environ Microbiol 69:6587-6596

Lancelot C (1983) Factors affecting phytoplankton extracellular release in the Southern Bight of the North Sea. Mar Ecol Prog Ser 12:115-121

Larsson U, Hagström Å (1982) Fractionated phytoplankton primary production, exudate release and bacterial production in a Baltic eutrophication gradient. Mar Biol 67:57-70

Livak KJ, Flood SJ, Marmaro J, Giusti W, Deetz K (1995) Oligonucleotides with fluorescent dyes at opposite ends provide a quenched probe system useful for detecting PCR product and nucleic acid hybridization. PCR Methods Appl 4:357-362

Manz W, Amann R, Ludwig W, Wagner M, Schleifer KH (1996) Application of a suite of 16S rRNA-specific oligonucleotide probes designed to investigate bacteria of the phylum Cytophaga-Flavobacter-Bacteroides in the natural environment. Microbiology 142:1097-1106

Pinhassi J, Azam F, Hemphala J, Long RA, Martinez J, Zweifel UL, Hagström Å (1999) Coupling between bacterioplankton species composition, population dynamics and organic matter degradation. Aquat Microb Ecol 17:13-26

Pinhassi J, Sala MM, Havskum H, Peters F, Guadayol Ò, Malits A, Marrasé C (2004) Changes in bacterioplankton composition under different phytoplankton regimens. Appl Environ Microbiol 70:6753-6766

Ploug H, Grossart HP, Azam F, Jørgensen BB (1999) Photosynthesis, respiration, and carbon turnover in sinking marine snow from surface waters of Southern California Bight: implications for the carbon cycle in the ocean. Mar Ecol Prog Ser 179:1-11

Porter KG, Feig YS (1980) The use of DAPI for identifying and counting aquatic microflora. Limnol Oceanogr 25:943-948

Rath J, Wu KY, Herndl GJ, DeLong EF (1998) High phylogenetic diversity in a marine-snow-associated bacterial assemblage. Aquat Microb Ecol 14:261-269

Editorial responsibility: Jed Fuhrman,

Los Angeles, California, USA
Redalje DG (1983) Phytoplankton carbon biomass and specific growth rates determined with the labeled chlorophyll a technique. Mar Ecol Prog Ser 11:217-225

Riemann L, Steward GF, Fandino LB, Campbell L, Landry MR, Azam F (1999) Bacterial community composition during two consecutive NE monsoon periods in the Arabian Sea studied by denaturing gradient gel electrophoresis (DGGE) of rRNA genes. Deep-Sea Res II 46: 1791-1811

Riemann L, Steward GF, Azam F (2000) Dynamics of bacterial community composition and activity during a mesocosm diatom bloom. Appl Environ Microbiol 66:578-587

Sambrook J, Fritsch EF, Maniatis T (1989) Molecular cloning: a laboratory manual, 2nd edn. Cold Spring Harbor Laboratory Press, Cold Spring Harbor, NY

Shewan JM, McMeekin TA (1983) Taxonomy (and ecology) of flavobacterium and related genera. Annu Rev Microbiol 37:233-252

Simon M, Glöckner FO, Amann R (1999) Different community structure and temperature optima of heterotrophic picoplankton in various regions of the Southern Ocean. Aquat Microb Ecol 18:275-284

Simon M, Grossart HP, Schweitzer B, Ploug H (2002) Microbial ecology of organic aggregates in aquatic ecosystems. Aquat Microb Ecol 28:175-211

Suzuki MT, Taylor LT, DeLong EF (2000) Quantitative analysis of small-subunit rRNA genes in mixed microbial populations via 5'-nuclease assays. Appl Environ Microbiol 66: $4605-4614$

Suzuki MT, Preston CM, Chavez FP, DeLong EF (2001) Quantitative mapping of bacterioplankton populations in seawater: field tests across an upwelling plume in Monterey Bay. Aquat Microb Ecol 24:117-127

Weller R, Glöckner FO, Amann R (2000) 16S rRNA-targeted oligonucleotide probes for the in situ detection of members of the phylum Cytophaga-FlavobacteriumBacteroides system. Appl Microbiol 23:107-114

Submitted: August 12, 2004; Accepted: June 23, 2005

Proofs received from author(s): September 27, 2005 